DOI https://doi.org/10.30525/978-9934-588-90-7-78

\title{
ОСОБЛИВОСТІ ВПРОВАДЖЕННЯ ІНТЕГРОВАНОГО ПРЕДМЕТНО-МОВНОГО ПІДХОДУ У МЕТОДИКУ НАВЧАННЯ АНГЛІЙСЬКОЇ МОВИ ЗА ПРОФЕСІЙНИМ СПРЯМУВАННЯМ МАЙБУТНІХ ЛІКАРІВ У ПОЛІНАЦІОНАЛЬНИХ ГРУПАХ
}

\author{
Вайнагій Т. М. \\ викладач кафедри громадського здоров'я і гуманітарних дисциилін \\ медичного факультету № 2 \\ ДВНЗ «Ужсгородський національний університет» \\ м. Ужгород, Украӥна
}

Неминучий процес інтеграції англійської мови та профільних навчальних дисциплін знайшов своє втілення в інтегрованому предметно-мовному підході, (або за Л. Мовчан (2011) - контекстномовному інтегрованому навчанні [2, с. 217]) і описаний у дослідженнях Д. Койл, Д. Марша та Ф. Худа (2010) [6]; Т. Мироненко, Л. Добровольської та О. Рудичик (2018) [1]; Л. Салехової та К. Григор'євої (2013) [4]; Е. Херроп (2012) [7]; В. Царенкової та С. Шпановської (2016) [5] та багатьох інших вітчизняних і зарубіжних науковців.

Термін Content Language Integrated Learning (CLIL), а разом з ним й інтегрований предметно-мовний підхід, був запропонований Д. Маршем (Фінляндія) у 1994 році [1; 3] і широко застосовується у закордонних закладах вищої освіти. Не зважаючи на те, що даний підхід й досі викликає безліч суперечок і має достатню кількість опонентів, він охопив більшу частину європейського простору, Азії і Латинської Америки.

Інтегрований предметно-мовний підхід (ІПМП) - це підхід до білінгвальної освіти, в якому зміст профільної дисципліни та іноземна мова вивчаються одночасно $[1 ; 3 ; 5 ; 6]$. На відміну від АМПС (англійської мови за професійним спрямуванням), яка базується на вивченні мови з урахуванням професійних потреб майбутнього фахівця, ІПМП має подвійний фокус - предметний зміст та англійську мову, до того ж зміщення пріоритетів можливе як в одну, так і в іншу сторону (моделі навчання, в яких пріоритет віддають професійній підготовці (content-led model) або мовній підготовці (language-led model)). Найчастіше пріоритетом $\epsilon$ навчання профільної дисципліни за допомогою англійської мови, тому оцінці піддаються отримані предметні знання. Модель «language-led» (у якій пріоритет віддається мові) дуже 
близька до АМПС. Відмінністю є те, що в ІПМП лінгвістичні навички оцінюються на основі професійних знань майбутнього фахівця.

ІПМП наближений до ідеї «своєчасного» навчання - «just in time learning» - i вважається максимально комунікативним підходом. Основна концепція полягає у поєднанні чотирьох «С» (зміст - Content, спілкування - Communication, культура - Culture, пізнання - Cognition) і вказує на пріоритети підходу, підкреслюючи його інноваційність для професійного розвитку майбутнього фахівця, враховуючи не лише професійні знання, комунікативну і міжкультурну компетентності, а й когнітивні навички $[5 ; 6 ; 7$, с. 58]. На основі принципу «навчальної підтримки» («scaffolded learning») [6; 7, с. 64] студенти формують прості розумові навички (LOTs - Low Order Thinking skills) запам'ятовування, класифікація, порівняння тощо і розумові навички вищого порядку (HOTs - High Order Thinking skills) - міркування, аналіз, синтез, оцінка тощо.

Не існує єдиної концепції того, хто саме може застосовувати ІПМП. Пріоритет віддається викладачам профільних дисциплін (носіям мови або вітчизняним викладачам, які володіють англійською мовою на рівні не нижче В2-C1 за шкалою CEFR (Common European Framework of Reference), а також методичною компетентністю IПМП). Але не виключається і можливість того, що володіючи певними методичними знаннями i навичками, за підтримки викладачів фахових дисциплін, викладач АМПС може з успіхом інтегрувати предметний зміст та АМПС.

Деякі вітчизняні 3ВО частково імплементують ІПМП у свої навчальні програми. Саме тому важливо зрозуміти і проаналізувати сильні та слабкі сторони впровадження ІПМП в умовах вищої освіти нашої держави 3 метою підвищення продуктивності навчання. Зокрема спостереження за навчальним процесом студентів спеціальності «Медицина» медичного факультету (з українською мовою навчання) та медичного факультету №2 (з англійською мовою навчання) ДВНЗ «Ужгородський національний університет» дозволило виокремити переваги та недоліки запровадження ІПМП у вітчизняних ЗВО.

Однією 3 головних переваг зазначеного підходу $\epsilon$ підвищення мотивації до вивчення АМПС серед майбутніх лікарів. Вивчення фахової медичної термінології стає більш цілеспрямованим, позаяк мова використовується для вирішення конкретних практичних комунікативних професійно орієнтованих завдань. Студенти пропускають через себе досить великий обсяг мовного і мовленнєвого матеріалу, тобто повноцінно занурюються у природнє англомовне фахове середовище. Окрім того, майбутні лікарі можуть краще пізнати і зрозуміти культуру 
англійської мови в цілому, а також міжнародні стандарти англомовної корпоративної культури медичної галузі, що сукупно призводить до формування соціокультурної компетентності студентів та значно полегшує англомовну комунікацію із закордонними колегами i пацієнтами у майбутніх ситуаціях фахового спілкування. Особливо важливим це $\epsilon$ для студентів, які навчаються в умовах полікультурного академічного середовища, а саме - в полінаціональних групах, де студенти $\epsilon$ представниками різних культур та мають відмінне сприйняття норм культурної, вербальної і невербальної поведінки в соціумі загалом та в медичній галузі зокрема. Розбіжності у поведінці студентів можуть призводити до частих непорозумінь під час виконання англомовних професійно орієнтованих групових і парних завдань, що пояснюється поділом культур на висококонтекстні та низькоконтекстні [8]. ІПМП дозволяє налагодити співпрацю студентів за допомогою концентрації на особливостях фахової етики англомовних країн та занурення у реалії англомовної професійної медичної культури.

Попри істотні переваги ІПМП у порівнянні з традиційними підходами до навчання АМПС та фахових дисциплін, сучасні реалії вітчизняних ЗВО викривають й значні недоліки цього підходу. Необхідною умовою для реалізації навчальних програм, в основу яких покладений ІПМП, є наявність високваліфікованих викладачів, які одночасно володіють достатнім регістром профільних знань та АМПС, здатні читати лекції та поводити практичні заняття англійською мовою. На жаль, у викладачів АМПС як правило відсутні достатні знання 3 фахових дисциплін i, навпаки, рівень володіння англійською мовою викладачів фахових дисциплін часто $є$ нижчим рівня В2. ДВНЗ «Ужгородський національний університет» зумів вирішити цю проблему, запровадивши безкоштовні заняття з англійської мови для викладачів профільних предметів з одного боку, а також за допомогою проведення регулярних консультацій викладачів-предметників з викладачами АМПС.

Ще однією проблемою $є$ низький рівень володіння англійською мовою студентами, що може призводити до збільшення навантаження, а також до певних психологічних проблем, пов'язаних із засвоєнням матеріалу англійською мовою. Ця проблема переважно відчувається серед студентів, мовою навчання яких $є$ українська (медичний факультет ДВНЗ «Ужгородський національний університет») і ускладнюється у полінаціональних групах, де студенти здобували середню освіту в межах різних національних освітніх систем, а тому мають різні рівні володіння англійською мовою. У ДВНЗ «Ужгородський національний університет» ця проблема була частково подолана запровадженням вивчення 
англійської мови протягом усього періоду навчання та збільшенням аудиторних годин для дисципліни.

У порівнянні зі студентами, які навчаються українською мовою, майбутні лікарі, які здобувають освіту англійською мовою, стикаються 3 меншою кількістю проблем під час навчання у межах ІПМП. Однак, акценти вихідців 3 різних країн значно ускладнюють розуміння студентами один одно, а також розуміння викладачем деяких студентів (наприклад, індійців, абсолютна більшість яких мають яскраво виражений акцент, складний для розуміння представниками інших національностей). У межах медичного факультету №2 ця проблема була частково вирішена запровадженням практичного курсу англійської мови для студентів першого курсу, а також введенням дисципліни АМПС для студентів другого курсу. Значна увага викладача АМПС до граматики та фонетики англійської мови, а також специфіки використання медичної термінології у межах зазначених дисциплін полегшує фаховою комунікацію студентів.

Варто зауважити, що не існує єдиної традиційної моделі ІПМП щодо навчання АМПС. Залежно від ступеня занурення в англійську мову розрізняють модель, близьку до повного занурення або повне занурення («hard CLIL») та модель, за якої рідна мова студентів використовується значною мірою для полегшення сприйняття предметної дисципліни («soft CLIL»), а також модель, у якій лише окремі модулі або навчальні предмети вивчаються англійською мовою («partial immersion») [1, с. 7]. Перша модель $є$ дієвою для студентів, мовою навчання яких є англійська. Друга модель буде ефективною для студентів 3 високим рівнем володіння англійською мовою, які здобувають освіту українською мовою. Третя модель $є$ результативною для студентів, які здобувають освіту українською мовою та мають низький і середній рівні володіння англійською мовою.

\section{Література:}

1. Мироненко Т.П., Добровольська Л.С., Рудичик О.М. Методика предметно-мовного інтегрованого навчання як засіб підготовки майбутніх фахівців. Young Scientist. 2018 . № 4.4 (56.4). С. 5-7.

2. Мовчан Л.Г. Використання досвіду Швеції у вітчизняній практиці навчання іноземних мов. Гуманізачія навчально-виховного проиесу. 2011. Спец. вип. 7. Ч. 2. С. 214-220.

3. Руднік Ю.В. Методика предметно-мовного інтегрованого навчання (CLIL): світовий досвід. Міжнар. наук.-практ. конф. 
[«Педагогіка та психологія: проблеми науки та практики»]. (м. Львів, Україна, 9 серпня 2013 року). Львів, 2013. С. 63-67.

4. Салехова Л.Л., Григорьева К.С. Content and Language Integrated Learning как основа формирования профессиональной иноязычной компетенции студентов технических вузов // Иностранный язык для профессиональных иелей: традищии и инновации: Сб. статей II заочного Республиканского симпозиума. Казань, 2013. С. 89-94.

5. Царенкова В.В., Шпановская С.И. К вопросу о лингвистических преимуществах предметно-языкового интегрированного обучения. Труды БГТУ. 2016. № 5 (187). С. 231-234.

6. Coyle Do, Hood Philip, Marsh David. Content and Language Integrated Learning. Cambridge: Cambridge University Press, 2010. 173 p.

7. Harrop E. Content and Language Integrated Learning (CLIL): Limitations and possibilities. Encuentro. 2012. 21. P. 57-70.

8. Lewis R.D. When Cultures Collide: Leading Across Cultures, Nicholas Brealey International; $3^{\text {rd }}$ ed, 2006. 625 p.

DOI https://doi.org/10.30525/978-9934-588-90-7-79

\title{
PECULIARITIES OF PODCASTING TECHNOLOGY IMPLEMENTATION DURING DISTANCE LEARNING OF STUDENTS OF PHILOLOGICAL SPECIALITIES WITHIN THE CONDITIONS OF THE QUARANTINE
}

\author{
Harmash T. A. \\ Candidate of Pedagogic Sciences, \\ Associate Professor of Foreign Philology Department \\ National Aviation University \\ Kyiv, Ukraine
}

The biggest challenge of the present time, the turbulence of which has no analogues in history, because the consequences caused by the global coronavirus epidemic, in its unprecedented value should be compared with extraordinary natural disasters or geopolitical wars, causes the transition to new educational standards that require of higher educational establishment to involve innovative education technologies to the educational process, to strengthen attention to the organization of self-directed learning of students, introduction of elements of distance learning into the educational process. In this regard, it is necessary to focus one's activities on the introduction of 292 